\title{
SURVEI TERHADAP PEMAHAMAN PENDIDIKAN SEKS DAN SIKAP/PERILAKU SEKS DI KALANGAN REMAJA DI DAERAH ISTIMEWA YOGYAKARTA
}

\author{
Das Salirawati*, Kartika Ratna P, M.*, M. Lies Endarwati** \\ *FMIPA Universitas Negeri Yogyakarta \\ **FE Universitas Negeri Yogyakarta \\ email: das.salirawati@yahoo.co.id
}

\begin{abstract}
Abstrak: Survei terhadap Pemahaman Pendidikan Seks dan Sikap/Perilaku Seks di Kalangan Remaja di Daerah Istimewa Yogyakarta. Penelitian ini bertujuan untuk mengetahui: (1) pemahaman tentang pendidikan seks dan sikap/ perilaku seks di kalangan remaja SMP dan SMA di DIY, (2) sikap/perilaku remaja terhadap berbagai permasalahan seks di sekitarnya, dan ada tidaknya perbedaan tingkat pemahaman tentang pendidikan seks berdasarkan lokasi (Kabupaten), jenis kelamin, dan tingkat sekolah (SMP dengan SMA). Penelitian ini didesain sebagai penelitian deskriptif dengan metode survei. Sampel diambil secara area proportional sampling. Seluruh data dianalisis secara deskriptif kuantitatif. Hasil penelitian menunjukkan besarnya pemahaman tentang pendidikan seks dan sikap/ perilaku seks di kalangan remaja SMP dan SMA di DIY sangat bervariasi, tetapi semuanya berada pada kategori rendah sampai tinggi, dengan rerata persentase terendah $26,3 \%$ dan tertinggi $74,9 \%$. Sikap/perilaku remaja terhadap berbagai permasalahan seks di sekitarnya banyak persoalan yang muncul dari jawaban yang diberikan responden yang perlu ditindaklanjuti dalam bentuk program pendidikan seks dan penelitian yang lebih mendalam. Berdasarkan hasil ANAVA dan uji-t menunjukkan ada perbedaan tingkat pemahaman tentang pendidikan seks diantara remaja SMP dan SMA di lima Kabupaten yang ada di DIY, tidak ada perbedaan tingkat pemahaman tentang pendidikan seks ditinjau dari jenis kelamin, tetapi ada perbedaan tingkat pemahaman tentang pendidikan seks ditinjau dan tingkat sekolah (SMP dan SMA). Secara keseluruhan hasil penelitian ini telah berhasil memotret tingkat pemahaman peserta didik SMP dan SMA di lima Kabupaten yang terdapat di DIY, meskipun dengan jumlah responden yang hanya 600 peserta didik. Hasil ini dapat menjadi acuan bagi pemilik kebijakan dalam memandang pentingnya pendidikan seks diberikan kepada remaja, khususnya remaja di DIY.
\end{abstract}

Kata kunci: survei, pendidikan seks, sikap/perilaku seks, remaja

\footnotetext{
Abstract: A Survey of Understanding-Perceiving Sexual Education and Sexual Behavior Among Teenagers in Yogyakarta Special Region. This study aims to: determine understanding and perception towards sex education to analyse among middle and high school teenagers in the Special Region of Yogyakarta (DIY) on various issues of sex, and (2) discuss whether there is any differences in the level of understanding of sex education by location (district), sex, and level of school. This study was designed as a descriptive study using survey method. Samples were taken with areas proportional sampling. All data were analyzed by descriptive quantitative. The results showed that an understanding of the magnitude of sex education among teenagers vary widely, with the average of the lowest percentage of $26.3 \%$ and the highest $74.9 \%$. the sexual perception and behavior of teenagers on various issues of sexual problems that arise from the respondents need to be followed up in the form of sex education programs and in-depth research. Based on the results of ANOVA and t-test showed no difference in the level of understanding of sex education among young people in junior and senior high schools between the five districts that exist in the province, there was no difference in the level
} 


\begin{abstract}
of understanding of sex education in terms of gender, but there are differences in the level of understanding of sex education between junior and senior high school. Overall the results of this study have successfully capture on the level of understanding of middle and high school students in the five district of Yogyakarta province. These results can be with as a futher for policy owners in view the importance of sex education for teenagers high schools in DIY.
\end{abstract}

Keywords: survey, sex education, perception, sexual behavior, teenagers

\section{PENDAHULUAN}

Saat ini bangsa Indonesia telah menyadari pentingnya mengutamakan akhlak mulia dalam proses pendidikan, seperti yang tercermin dalam acuan operasional penyusunan kurikulum. Pemerintah menyadari hanya generasi yang berakhlak mulia yang dapat dididik menjadi generasi yang mudah diarahkan dan berhasil, sehingga selain cerdas intelektualnya juga sekaligus berkarakter dan berkualitas akhlaknya.

Era globalisasi sudah merambah ke semua negara, termasuk negara kita. Kecanggihan IPTEK yang salah satunya ditandai dengan semakin canggihnya teknologi informasi dan komunikasi telah membawa pada cepatnya informasi diterima tanpa batas ruang dan waktu. Selain berdampak positif, kondisi tersebut juga membawa dampak negatif yang membahayakan bagi perkembangan masyarakat dunia. Terlebih bagi masyarakat di negara berkembang, seperti Indonesia, yang masyarakatnya sangat mudah tergoda untuk meniru dan mengikuti apapun perkembangan di negara-negara maju. Salah satu dampak negatif yang saat ini sudah pada tingkat mengkhawatirkan dan penting diwaspadai adalah maraknya situs-situs dewasa di internet yang sangat mudah diakses anak-anak usia remaja dimanapun dan kapanpun mereka inginkan. Sekolah yang hanya dapat mengawasi $30 \%$ ( \pm 7 jam) setiap hari dari kegiatan anak, tidak mampu memberikan pemahaman pengetahuan tentang seks kepada anak didiknya. Sedangkan orangtua yang memiliki waktu $70 \%$ ( \pm 17 jam), pada kenyataannya disibukkan bekerja untuk memenuhi hidup yang layak bagi anakanaknya (Kemendiknas, 2010).

Remaja dalam Bahasa Inggris disebut adolescence yang berasal dari Bahasa Latin adolescere yang berarti tumbuh ke arah kematangan (Pratiwi, 2005:1). Kematangan itu bukan hanya kematangan yang bersifat fisik, namun juga kematangan sosial dan psikologis. Masa remaja adalah masa transisi dari kanak-kanak menuju dewasa. Anak-anak yang menginjak bangku SMP adalah awal dari masa remaja. Demikian pula anak SMA yang sangat bergejolak jiwa remajanya. Gejolak mental emosional seringkali dimunculkan oleh remaja disebabkan adanya perubahan draktis akibat perkembangan fisik dan psikis.

Perubahan psikologis adalah perubahan mental emosional dari alam anak ke alam dewasa. Mereka disebut anak sudah tidak mau, tetapi dewasa masih jauh dari kematangan sikap dan pola pikir. Selain itu juga terjadi perkembangan psikoseksual, yaitu terjadi menstruasi pada wanita dan politio (mimpi basah) pada remaja pria membuat mereka menjadi cemas dan tertekan (Lanson, 1987:19).

Usia remaja rawan untuk melakukan hal-hal di luar batas kendali normal, apalagi jika terlepas dari pengawasan orangtua. Godaan-godaan tersebut mengarah pada kerusakan moral dan kesehatan, seperti pergaulan bebas, minuman keras, seks bebas, bahkan yang terparah terjerumus narkoba. Hanya melalui dasar pendidikan 
agama yang kuat dan pemberian bekal pendidikan seks yang benar dari kita (guru dan orangtua), mereka dapat terbebas dari godaan-godaan yang merusak masa depannya.

Salah satu bagian penting pada tahap perkembangan remaja adalah terjadinya pubertas. Pubertas berasal dari kata Latin pubes yang berarti akil baligh (Pratiwi, 2005:13). Pubertas adalah periode kematangan fisik yang melibatkan perubahan hormonal dan tubuh. Perubahan itu terutama muncul pada masa awal remaja yang melibatkan perubahan fisik, psikologis, dan perawatan kesehatan. Perubahan pada masa pubertas berbeda pada masing-masing anak.

Pada masa pubertas terjadi perubahan fisik pada anak laki-laki dan anak perempuan yang berlangsung secara bertahap. Ciri-ciri fisik pada perempuan pada masa pubertas (Anonim, 1998: 16-22) adalah pertumbuhan payudara, pertumbuhan rambut di sekitar ketiak dan vagina, menstruasi, panggul mulai melebar dan membesar, alat kelamin berwarna menjadi lebih gelap, tinggi dan berat badan bertambah, kulit menjadi lebih berminyak sehingga memungkinkan tumbuhnya jerawat, keringat keluar lebih banyak. Sedangkan pada laki-laki adalah pertumbuhan testes dan skrotum, pertumbuhan rambut di sekitar ketiak dan kemaluan, pertumbuhan penis dan kelenjar prostat menjadi lebih besar dan berwarna lebih gelap, perubahan suara menjadi lebih berat, ejakulasi dapat terjadi saat mimpi basah atau saat melakukan masturbasi, bulu tumbuh di sektar wajah dan dada, tubuh menjadi lebih berotot, berkeringat lebih banyak, kulit menadi berminyak dan memungkinkan tumbuhnya jerawat.

Perubahan yang terjadi pada masa ini tidak hanya fisik, namun juga perubahan psikis. Perubahan psikis yang sering kita lihat pada remaja diantaranya ingin mandiri, ingin diakui kedewasaan, tidak mau diatur lagi oleh orangtua. Mereka lebih perhatian terhadap diri sendiri, seperti lebih sering berdandan, bercermin, dan lebih perhatian serta ingin diperhatikan oleh lawan jenisnya. Dengan perubahan yang demikian, maka sangat rawan bagi remaja untuk mudah dipengaruhi teman bergaulnya, baik di sekolah maupun lingkungan dimana ia tinggal. Oleh karena itu pendampingan orangtua atau guru di sekolah dibutuhkan agar mereka tidak salah dalam pergaulan.

Seks bukan sesuatu yang tabu untuk dibicarakan dan harus diperkenalkan sedini mungkin pada anak-anak dengan bahasayangsesuaiusiamereka.Pendidikan seks dalam keluarga sangat penting dilakukan sebagai antisipasi pemahaman informasi seks yang salah dari pihak-pihak yang tidak bertanggungjawab. Selain itu sekolah sebagai media pendidikan formal juga berkewajiban untuk memberikan bekal pengetahuan tentang pendidikan seks kepada anak didiknya agar mereka tidak salah dalam bergaul (Madan, 2004:3).

Di luar negeri (misal Perancis, Amerika), pendidikan seks secara formal diberikan kepada anak-anak setingkat SD dan SMP di Indonesia dengan tujuan agar mereka mengetahui akibat yang ditimbulkan bila melakukan hubungan badan dan bagaimana cara mengatasinya. Secara terang-terangan beberapa sekolah di luar negeri menyediakan alat kontrasepsi (misal: kondom) bagi peserta didiknya yang ingin menggunakannya. Anak-anak Indonesia tidak mendapatkan pendidikan seks sebagai mata pelajaran formal tetapi hanya terselip diantara mata pelajaran biologi, PPKn, atau hanya sekedar nasihat/ informasi tambahan di tengah-tengah pelajaran (sebagai hidden curriculum). Oleh karena itu, bagi anak-anak yang rasa ingin tahunya tinggi kemudian mencoba mencari informasi sendiri dari berbagai sumber, seperti internet, $C D$, atau media lainnya. Bila ini tidak termonitoring, baik oleh orangtua, saudara, maupun 
guru, maka dapat saja informasi yang diperoleh tersebut disalahgunakan karena penasaran atau keinginan membuktikan sesuatu yang dilihatnya.

Pendidikan seks bukan berarti membatasi pergaulan mereka terhadap sesama teman, namun bertujuan agar mereka lebih berhati-hati dalam bergaul. Bagaimanapun pergaulan sangat penting, karena kita juga harus dapat menanamkan cara bersosialisasi yang baik pada mereka, agar anak-anak kita tidak menjadi "kuper" (kurang pergaulan). Mereka butuh mengekspresikan diri dan mencari identitas diri, tugas kita sebagai orang-tua membekali pendidikan seks, mengawasi dan mengingatkan mereka bila menyimpang dari jalur yang benar.

Berdasarkan hal tersebut, maka perlu kiranya dilakukan survei tentang seberapa besar pemahaman remaja terhadap pendidikan seks dan permasalahannya. Dipilihnya sampel anak SMP dan SMA, karena mereka termasuk remaja yang paling rawan terjebak dalam pergaulan bebas dan sedang dalam pencarian identitas diri yang ditandai dengan keinginan yang kuat untuk mencoba sesuatu yang baru dalam hidupnya. Melalui survei ini diharapkan dapat diperoleh data empirik mengenai tingkat pemahaman pendidikan seks anak-anak SMP dan SMA di DIY. Harapannya, hasil survei ini dapat menjadi masukan bagi Dinas Pendidikan DIY khususnya dalam merancang program penyuluhan pendidikan seks di sekolahsekolah secara periodik, sebagai langkah menyelamatkan remaja generasi penerus bangsa agar berkarakter terpuji, santun, dan maju dalam berkarya.

Permasalahan yang akan dijawab dalam penelitian ini adalah seberapa besar pemahaman tentang pendidikan seks dan sikap/perilaku seks di kalangan remaja SMP dan SMA di Daerah Istimewa Yogyakarta (DIY), sikap/perilaku remaja terhadap berbagai permasalahan seks di sekitarnya, dan ada tidaknya perbedaan tingkat pemahaman tentang pendidikan seks berdasarkan lokasi (Kabupaten), jenis kelamin, dan tingkat sekolah (SMP dengan SMA).

\section{METODE}

Penelitian ini didesain sebagai penelitian deskriptif dengan metode survei terhadap peserta didik SMP dan SMA di lima Kabupaten yang ada DIY. Variabel penelitian ini adalah pemahaman tentang pendidikan seks ditinjau dari berbagai pengertian penting dan mitos-mitos yang berkaitan dengan pendidikan seks bagi remaja dan sikap/perilaku seks di kalangan remaja. Populasi dalam penelitian ini adalah seluruh peserta didik SMP dan SMA dari lima Kabupaten yang ada di DIY, yaitu Kota, Sleman, Bantul, Kulon Progo, dan Gunung Kidul. Sampel diambil secara area proportional sampling, yaitu dengan mengambil sejumlah sampel berdasarkan area secara proporsional, baik dalam hal jumlah SMP dan SMA yang ada di setiap Kabupaten maupun jumlah peserta didik perempuan dan laki-laki. Instrumen berupa angket yang divalidasi secara logis, berjumlah 55 butir pertanyaan, terdiri dari 30 soal pilihan ganda, 4 pertanyaan tema tentang mitos-mitos seputar seks, dan 21 soal setengah terbuka mengenai sikap/perilaku seks di kalangan remaja.

\section{HASIL DAN PEMBAHASAN}

Berdasarkan data yang diperoleh dari pengisian angket pemahaman tentang pendidikan seks dan sikap/ perilaku seks peserta didik SMP dan SMA di DIY menunjuk-kan bahwa besarnya pemahaman peserta didik terhadap pendidikan seks yang meliputi 3 aspek utama, yaitu pengetahuan, persepsi terhadap mitos-mitos seputar seks, dan sikap/perilaku seks bervariasi.

Adapun hasil analisis data aspek utama pertama (pengetahuan) yang terdiri dari empat aspek berdasarkan asal Kabupaten penelitian (Kota, Bantul, 
Sleman, Kulon Progo, dan Gunung Kidul), jenis kelamin (laki-laki dan perempuan), dan tingkat sekolah (SMP dan SMA) dapat disajikan pada Tabel 1, 2, dan 3 .

Pemahaman tentang aspek organ reproduksi dan pubertas Kulon Progo tertinggi, disusul oleh Kabupaten Sleman, Kota, Gunung Kidul, dan terakhir Bantul. Pada aspek pemahaman tentang fertilisasi dan kehamilan, kembali Kulon Progo mendominasi, disusul oleh Kota, Sleman, Bantul, dan Gunung Kidul. Demikian pula untuk dua aspek lainnya, yaitu kontrasepsi dan aborsi dan kelainan dan PMS, Kabupaten Kulon Progo memiliki rerata tertinggi dan Kabupaten Gunung Kidul terendah. Data ini menunjukkan bahwa meskipun Kulon Progo bukan Kota, tetapi ternyata pemahaman peserta didik terhadap pendidikan seks lebih tinggi dibandingkan Kabupaten lainnya. Sedangkan untuk Kabupaten Gunung Kidul yang memang berada jauh dari Kota memiliki rerata terendah.

Tabel 1. Rerata Pengetahuan Berdasarkan Kabupaten

\begin{tabular}{llccccc}
\hline \multirow{2}{*}{ No } & \multicolumn{5}{c}{ Aspek } & \multicolumn{5}{c}{ Rerata Pengetahuan (\%) } \\
\cline { 3 - 7 } & Kota & Bantul & Sleman & KP & GK \\
\hline 1. & Organ Reproduksi dan Pubertas & 63,5 & 54,8 & 65,4 & 68,1 & 58,8 \\
2. & Fertilisasi dan Kehamilan & 39,5 & 29,8 & 33,3 & 44,0 & 29,0 \\
3. & Kontrasepsi dan Aborsi & 35,0 & 26,3 & 36,3 & 48,8 & 35,2 \\
4. & Kelainan dan Penyakit Menular Seksual & 66,0 & 64,3 & 67,2 & 74,2 & 54,7 \\
\hline \multicolumn{1}{c}{ Rerata } & 51,0 & 43,8 & 50,6 & 58,8 & 44,4 \\
\hline & Kriteria & S & S & S & S & S \\
\hline
\end{tabular}

Tabel 2. Rerata Pengetahuan Berdasarkan Jenis Kelamin

\begin{tabular}{llcc}
\hline \multirow{2}{*}{ No } & \multicolumn{1}{c}{ Aspek } & \multicolumn{2}{c}{ Rerata Pengetahuan (\%) } \\
\cline { 3 - 4 } & & 61,6 & Laki-laki \\
1. & Organ Reproduksi dan Pubertas & 34,9 & 62,7 \\
2. & Fertilisasi dan Kehamilan & 34,7 & 35,4 \\
3. & Kontrasepsi dan Aborsi & 63,7 & 37,9 \\
4. & Kelainan dan Penyakit Menular Seksual & 48,7 & 66,8 \\
\hline \multicolumn{2}{c}{ Rerata } & Sedang & Sedang \\
\hline
\end{tabular}

Tabel 3. Rerata Pengetahuan Berdasarkan Tingkat Sekolah

\begin{tabular}{llcc}
\hline \multirow{2}{*}{ No } & \multicolumn{1}{c}{ Aspek } & \multicolumn{2}{c}{ Rerata Pengetahuan (\%) } \\
\cline { 3 - 4 } & & SMP & SMA \\
\hline 1. & Organ Reproduksi dan Pubertas & 55,4 & 68,9 \\
2. & Fertilisasi dan Kehamilan & 27,7 & 42,6 \\
3. & Kontrasepsi dan Aborsi & 30,6 & 42,1 \\
4. & Kelainan dan Penyakit Menular Seksual & 58,1 & 72,4 \\
\hline \multicolumn{2}{c}{ Rerata } & 43 & 56,5 \\
\hline & Kriteria & Sedang & Sedang \\
\hline
\end{tabular}


Rerata pemahaman pengetahuan pada keempat aspek pengetahuan jika ditinjau dari jenis kelamin, maka antara peserta didik laki-laki dan perempuan hampir sama (selisihnya relatif kecil), meskipun peserta didik perempuan memiliki rerata sedikit lebih besar dari rerata peserta didik laki-laki. Namun pada aspek kontrasepsi dan aborsi, rerata peserta didik perempuan relatif lebih besar $(37,9 \%)$ dibandingkan laki-laki $(34,7 \%)$. Hal ini dapat dipahami, karena sebagian besar alat kontrasepsi ditujukan untuk perempuan dan aborsi merupakan tindakan yang berkaitan pula dengan perempuan.

Peserta didik SMA memiliki rerata pemahaman pengetahuan pendidikan seks yang jauh lebih tinggi pada keempat aspek. Hal ini wajar karena mereka lebih dewasa dan juga telah memperoleh materi pelajaran yang berkaitan dengan organorgan biologis lebih banyak dibandingkan peserta didik SMP. Bahkan pada aspek fertilisasi dan kehamilan (42,6\%) dan aspek kelainan dan PMS $(72,4 \%)$ jauh lebih tinggi daripada rerata peserta didik SMP pada kedua aspek $(27,7 \%$ dan $58,1 \%)$.

Persepsi peserta didik terhadap mitos-mitos seputar seks antar Kabupaten bervariasi dengan dominasi pertama tetap diduduki oleh Kabupaten Kulon Progo dan terendah Gunung Kidul. Demikian pula jika ditinjau dari jenis kelamin, peserta didik perempuan sedikit lebih besar persepsinya $(59,1 \%)$ atau hampir berimbang dengan laki-laki (58,3\%). Ditinjau dari tingkat pendidikan, maka peserta didik SMP ternyata sedikit lebih besar persepsinya $(59,2 \%)$ daripada SMA (58,3\%). Hal ini berkebalikan dengan hasil rerata pada aspek pengetahuan.

Besarnya persepsi terhadap mitosmitos seputar seks ditinjau dari tingkat seko-lah, empat Kabupaten menunjukkan hasil yang sama, yaitu persepsi peserta didikSMPlebih kecil daripada peserta didik SMA, namun hasil rerata menunjukkan sebaliknya. Hal ini disebabkan Kulon Progo berkontribusi sangat besar untuk persentase peserta didik SMP, yaitu 81,3\%, padahal peserta didik SMA relatif kecil, yaitu sebesar 68,5\%.

Ditinjau dari jenis kelamin dan tingkat sekolah dari masing-masing Kabupaten menunjukkan hasil yang tidak selalu sama, artinya perempuan tidak selalu lebih besar daripada laki-laki seperti yang ditunjukkan pada rerata keseluruhan. Sebagai contoh, untuk Kota peserta didik SMP perempuannya memiliki persentase persepsi lebih kecil daripada laki-laki, sebaliknya pada tingkat SMA laki-lakinya jauh lebih besar persepsinya daripada perempuan. Demikian pula untuk Kabupaten Bantul dan Kulon Progo. Namun hasil yang sama ditunjukkan oleh Kabupaten Sleman dan Gunung Kidul dimana untuk Sleman pada tingkat SMP dan SMA peserta didik perempuan lebih besar persepsinya $(56,7 \%$ dan $60,1 \%)$ dibanding laki-laki $(53,9 \%$ dan 54,7\%), sedangkan untuk Gunung Kidul sebaliknya, yaitu pada tingkat SMP dan SMA peserta didik laki-laki lebih besar persepsinya $(50,0 \%$ dan $52,3 \%)$ dibanding perempuan $(48,3 \%$ dan $50,9 \%)$.

Beberapa persepsi yang ditanyakan pada bagian angket ini menunjukkan respon yang sebagian besar benar atau salah pada beberapa pernyataan. Persepsi yang salah dapat berbahaya, karena pola pikir yang salah dapat menjerumuskan pada perilaku yang salah pula. Sebagai contoh untuk pernyataan "Sering melakukan masturbasi/onani dapatmenyebabkan kemandulan" sebagian besar peserta didik SMP dan SMA menjawab "salah", dan itu merupakan persepsi yang benar, karena masturbasi/onani bukan merupakan penyebab dari kemandulan dan biasa dilakukan di kalangan remaja sebagai perilaku lazim.

Pada pernyataan seputar hubungan seksual dan kehamilan, ada beberapa persepsi yang salah, diantaranya yang 
mencolok pada nomor 32(1), yaitu "Berhubungan seksual untuk pertama kalinya ditandai dengan keluarnya darah dari vagina", sebagian besar menjawab "benar", padahal persepsi tersebut "salah", sebab keluarnya darah dari vagina tidak selalu menyertai pada saat pertama kali berhubungan seksual. Banyak faktor penyebabnya, misal seorang atlit yang banyak gerakan yang dapat menyebabkan sobeknya selaput dara, tebal tipisnya selaput dara, dan juga bersepeda. Kesalahan persepsi justru terjadi pada peserta didik SMA, yaitu sebanyak 237 responden (79\%), sedangkan di SMP malah lebih kecil yang salah persepsi, yaitu 155 responden (51,7\%) seimbang dengan persepsi yang benar.

Untuk pernyataan 32(3), yaitu "Mela-kukan hubungan seks jika hanya sekali pasti tidak hamil", sebagian besar peserta didik SMP dan SMA memiliki persepsi yang benar, yaitu menjawab "salah", artinya sebagian besar responden mengetahui bahwa berhubungan seks sekali saja dapat menyebabkan kehamilan. Pernyataan berikutnya, yaitu nomor 32(6) yang berbunyi "Mencuci vagina setelah berhubungan seksual mencegah terjadinya kehamilan", ternyata hampir sebagian besar responden menyata-kan "salah", padahal harusnya "benar". Hal ini karena mereka tidak pernah memperoleh informasi di sekolah maupun mencari tahu dari sumber informasi lain (internet, koran, majalah, dan lain-lain). Persepsi yang salah justru lebih banyak dialami peserta didik SMA (256 atau 85,3\%) daripada SMP (234 atau 78\%).

Ada respon yang menarik diberikan responden SMA, yaitu pada butir pernyataan 32(7) yang berbunyi "Petting (melakukan hubungan seksual tanpa penetrasi penis ke dalam vagina) tidak dapat menyebabkan kehamilan", ternyata sebagian besar peserta didik SMA menyatakan "benar" (60,3\%), padahal petting dapat menyebabkan ke- hamilan. Sebaliknya pada peserta didik SMP persepsi benar dan salah jumlahnya berimbang, yaitu jumlah yang menjawab "benar" sebanyak 149 (49,7\% persepsinya salah) dan jumlah yang menjawab "salah" sebanyak 151 (50,3\% persepsinya benar).

Hasil sebaliknya ditunjukkan pada pernyataan 32(8), yaitu "Berhubungan seks saat menstruasi tidak menyebabkan kehamilan", dimana peserta didik SMP sebagian besar persepsinya salah dengan menjawab "salah" sebanyak 190 orang (63,3\%), sedangkan peserta didik SMA sebagian besar persepsinya benar dengan menjawab "benar" sebanyak 180 orang (60\%).

Pada butir pernyataan 33(1) yang berkaitan dengan mitos seputar kontrasepsi dan aborsi, yaitu "Kondom 100\% aman untuk mencegah kehamilan" sebagian besar persepsi responden benar dengan menjawab "salah" pernyataan tersebut. Hal ini merupakan sesuatu yang menggembirakan, karena mereka tahu bahwa dengan menggunakan kondom bukan berarti mereka dapat menganut seks bebas.

Salah satu pernyataan seputar kelainan dan PMS adalah butir 34(1), yaitu "PMS dapat dicegah dengan mencuci alat kelamin", dimana pernyataan ini sejalan dengan pernyataan pada butir 32(6) tentang mencuci vagina dapat mencegah kehamilan. Hasilnya menunjukkan kecenderungan persepsi yang sama, yaitu sebagian besar salah persepsi dengan menjawab "salah", padahalnya harusnya "benar". Hasil ini membawa kita pada kesimpulan bahwa sebagian besar remaja yang menjadi responden tidak mengetahui fungsi menjaga kebersihan alat kelamin, mereka beranggapan buka hal yang penting dilakukan. Hal inilah yang perlu disampaikan kepada mereka melalui pendidikan seks yang terprogram dengan baik.

Seperti yang sering dibicarakan di masyarakat, ternyata data yang diperoleh 
dari respon jawaban peserta didik yang menjadi sampel pada bagian ketiga, yaitu sikap/ perilaku seks menunjukkan hasil yang sesuai dengan realita, yaitu bahwa sebagian besar peserta didik memperoleh informasi yang berkaitan dengan kesehatan reproduksi bukan dari keluarganya melainkan dari media cetak/ elektronik, yang disusul kemudian dari sekolah/guru. Hasil ini menunjukkan bahwa keluarga bukan tempat bertanya bagi anak-anaknya, dan hal ini perlu menjadi perhatian kita semua, karena pemahaman mereka tentang informasi yang diperoleh dari media belum tentu benar.

Pada pertanyaan "Pada usia berapa kamu pertama kali menstruasi atau mimpi basah?", maka jawabannya sangat variatif. Berdasarkan analisis data, perempuan pertama kali menstruasi banyak terjadi di usia 11, 12, dan 13 tahun, yaitu sebanyak 56,127 , dan 83 responden, atau di kelas 5, 6 SD, dan 7 SMP. Banyaknya perempuan mengalami menstruasi di usia dini disebabkan oleh berbagai faktor. Menurut Wirahadi-kusumah, 1989:34-35), adanya kelebihan protein yang diberikan di usia dini dengan tujuan agar pertumbuhan anak menjadi cepat sebenarnya tidak tepat, karena protein tersebut akan mempengaruhi produksi somatopedin, yaitu suatu fasilitator pertumbuhan yang diproduksi oleh hati sebagai hormon pertumbuhan (growth hormone) yang berfungsi sebagai penggerak utama kematangan seksual (www.menarkhe. com). Protein juga berfungsi dalam sintesis beberapa hormon yang penting bagi remaja putri, yaitu hormon estrogen, progesteron, hormon lutinasi (Luteinizing Hormone/LH), dan hormon perangsang folikel (Folikel Stimulating Hormone/FSH) yang berperan ketika mereka memasuki masa pubertas, yaitu masa menstruasi awal atau menarkhe.

Selain protein, kelebihan konsumsi karbohidrat dan lemak juga dapat memicu terjadinya menstruasi (menarkhe) dini akibat kelebihan berat badan (obesitas). Hal ini sejalan dengan penelitian yang dilakukan Dr. Rajalaksmi Laksmana dari Universitas Cambridge yang menyatakan sebagian besar kasus menstruasi dini berkaitan dengan jumlah lemak di dalam tubuh perempuan (www.tempointeraktif. com).

Menstruasi dini perlu diwaspadai karena selain anak belum mampu secara benar merawat organ reproduksinya, juga berpengaruh terhadap datangnya menopause dini yang berakibat menipisnya kulit dan keriput karena semakin menurunnya estrogen. Selain itu terjadi penumpukan lemak di beberapa tempat tertentu di bawah kulit, seperti di pinggang dan dilengan bagian atas (Lanson, 1987: 158). Perempuan yang mengalami menstruasi dini akan mengalami masa menopause secara dini pula. Hal ini berarti pada usia yang relatif masih muda, hormon estrogen sudah tidak ada, padahal hormon ini berfungsi mencegah serangan jantung dan melindungi tulang. Dengan demikian menopause dini berakibat hilangnya perlindungan terhadap serangan jantung dan tulang, sehingga resiko terkena gangguan jantung dan tulang relatif besar (Anonim, 2001:28).

Tidak jauh berbeda dengan perempuan, maka laki-laki mengalami mimpi basah pertama kali banyak terjadi di usia 11, 12, 13, dan 14 tahun, yaitu berturut-turut sebanyak 35, 108, 93 dan 41 responden. Jika menstruasi dan mimpi basah dipandang sebagai titik awal kedewasaan manusia, maka data ini menunjukkan bahwa perempuan lebih banyak yang memasuki kedewasaan terlebih dahulu dibandingkan laki-laki, karena pada 9-12 tahun lebih banyak perempuan yang mengalami menstruasi pertama kali, meskipun ada dua laki-laki yang mimpi basah pada usia yang masih belia ( 8 tahun). Adanya satu perempuan yang menstruasi pertama kali di usia 18 tahun kemungkinan ada semacam 
gangguan daur menstruasi yang berkaitan dengan pertumbuhan hormonal tubuh.

Secara berimbang responden menjawab pertanyaan pernah tidaknya melihat video porno. Ada 308 menyatakan pernah (51,3\%) dan 292 menyatakan tidak pernah $(48,7 \%)$. Hasil ini cukup menggembirakan, karena berarti masih banyak generasi muda yang tidak terjebak untuk melihat video porno yang dapat berakibat kurang baik bagi perkembangan mentalnya. Sebanyak 91 responden $(29,3 \%)$ menyatakan terangsang untuk melihat lagi video porno, tetapi secara berkebalikan ada 90 responden $(28,9 \%)$ menyatakan takut dosa. Hasil ini menunjukkan betapa menonton video porno dapat menyebabkan mereka ketagihan, dan ini hal yang harus dicegah dimana keluarga harusnya berperan mengawasi.

Ada 113 responden (36,5\%) menyatakan melihat video porno karena didorong rasa ingin tahu dan 93 responden $(30,0 \%)$ karena iseng. Berangkat dari rasa ingin tahu dan iseng inilah dapat berakibat fatal bagi mereka. Apalagi mereka sebagian besar melihat video porno bersama teman-teman (172 responden, 55,8\%) dan menonton sendiri (123 responden, $39,9 \%$ ). Hasil ini sejalan dengan jawaban mereka bahwa video porno tersebut sebagian besar menyatakan diperoleh dari teman (198 responden, 64,3\%) dan cari sendiri (73 responden, 23,7\%).

Jaman sudah berubah, sehingga pacaran pun sudah menjadi sesuatu yang wajar di era sekarang ini. Ada 404 responden $(68,5 \%)$ menyatakan sudah pernah pacaran. Dari 404 responden tersebut, mereka berpacaran ada yang sudah sampai ciuman bibir (43 responden, 10,3\%) dan bahkan petting dan berhubungan seksual meskipun masingmasing hanya 2 responden $(0,5 \%)$. Setelah ditelusuri dari data yang dikumpulkan, ternyata dua responden yang pernah melakukan petting berasal dari Kabupaten
Gunung Kidul, keduanya dari SMA swasta, sedangkan dua responden yang telah melakukan hubungan seksual tersebut satu peserta didik dari SMA yang sama dan satunya dari SMA di Kabupaten Bantul. Meskipun dua dari 600 responden ini relatif sangat sedikit, tetapi hal ini perlu diwaspadai, karena bukan tidak mungkin ada beberapa responden yang tidak jujur meskipun tidak ada nama yang harus dicantumkan dalam angket.

Respon ketika menjawab pertanyaan "Apakah kamu pernah menggunakan alat kontrasepsi?', ternyata sebanyak 122 responden $(95,3 \%)$ menjawab tidak pernah, sedangkan ada 6 responden yang menjawab pernah. Hal ini berarti keenam responden tersebut otomatis pernah melakukan hubungan seksual. Setelah ditelusuri dari data yang dikumpulkan ternyata keenam responden tersebut, dua dari Kota dan keduanya peserta didik SMP laki-laki, dua dari Kabupaten Gunung Kidul keduanya peserta didik laki-laki dan perempuan yang duduk di SMP juga, dan satu peserta didik SMP dari Kabupaten Bantul dan satu peserta didik perempuan SMA dari Kabupaten Kulon Progo.

Kelima peserta didik laki-laki menggunakan kondom, sedangkan perempuan menggunakan pil KB. Informasi ini sangat memprihatinkan kita, karena ternyata justru anak-anak usia SMP yang banyak menggunakan alat kontrasepsi daripada SMA. Hal ini karena usia SMP (12-15 tahun) merupakan usia transisi dari anakanak menuju remaja dan di sinilah gejolak remajanya tumbuh yang ditandai dengan serba ingin tahu dan mencoba sebagai cara untuk menunjukkan eksistensi dirinya.

Hasil ANAVA untuk mengetahui ada tidaknya perbedaan pemahaman pengetahuan tentang seks antarkabupaten menunjukkan bahwa nilai signifikansiyang dihasilkan pada masing-masing aspek pengetahuan sebesar $0,000 \quad(\mathrm{p}<0,05)$ yang berarti bahwa terdapat perbedaan pemahaman peserta didik terhadap 
pengetahuan tentang organ reproduksi dan pubertas, fertilisasi dan kehamilan, kontrasepsi dan aborsi, dan kelainan dan penyakit menular seksual antarkabupaten.

Selanjutnya untuk mengetahui antarkabupaten mana yang berbeda secara signifikans, maka dilakukan analisis uji-t antar subjek. Hasilnya menunjukkan ada beberapa kabupaten yang menunjukkan perbedaan, namun ada pula yang menunjukkan perbedaan dari keempat aspek yang ada.

Sebagai contoh, untuk pemahaman pengetahuan tentang organ reproduksi dan pubertas tidak ada perbedaan antara Sleman dengan Kota, antara Sleman dengan Kulon Progo yang ditunjukkan dengan harga $p>0,05$. Demikian juga untuk pemahaman pengetahuan tentang fertilisasi dan kehamilan, tidak ada perbedaan antara Bantul dengan Gunung Kidul, Bantul dengan Sleman, Gunung Kidul dengan Sleman, dan Kota dengan Kulon Progo yang ditunjukkan dengan harga signifikansi lebih dari 0,05.

Secara umum tidak dapat digeneralisasikan Kabupaten mana yang berbeda dari Kabupaten yang lain, karena setiap aspek perbedaan tersebut tidak ditemukan antar dua Kabupaten yang sama.

Ada tidaknya perbedaan pemahaman peserta didik berdasarkan jenis kelamin ditentukan dengan analisis uji-t. Hasilnya menunjukkan keempat aspek tersebut terbukti tidak ada perbedaan yang signifikan antara peserta didik laki-laki dan perempuan yang ditunjukkan dengan harga $t$ hitungyang disertai harga taraf signifikansi (p) lebih besar dari 0,05 ( $p>0,05)$.

Analisis uji-t dilakukan pula untuk mengetahui ada tidaknya perbedaan pemahaman pada keempat aspek pengetahuan berdasarkan tingkat sekolah, yaitu SMP dan SMA. Hasilnya pada keempat aspek pengetahuan ada perbedaan yang signifikans antara peserta didik SMP dan SMA yang ditunjukkan dengan harga signifikansi (p) lebih kecil dari 0,05 $(\mathrm{p}<0,05)$.

Hasil ANAVA mengenai data persepsi peserta didik terhadap mitos-mitos seputar seks menunjukkan bahwa terdapat perbedaan persepsi berdasarakan kabupaten yang dapat dilihat dari harga taraf signifikansi (p) sebesar 0,000 (p < 0,05) dan harga F sebesar 76,588.

Secara keseluruhan hasil penelitian ini telah berhasil memotret tingkat pemahaman peserta didik SMP dan SMA di lima Kabupaten yang terdapat di DIY, meskipun dengan jumlah responden yang hanya 600 peserta didik. Setidaknya dengan hasil ini dapat menjadi acuan bagi pemilik kebijakan yang berkaitan dengan pendidikan seks bagi perkembangan mental dan masa depan anak didik kita.

\section{SIMPULAN}

Berdasarkan data yang telah dianalisis dari responden peserta didik SMP dan SMA yang ada di lima Kabupaten di DIY, maka dapat disimpulkan besarnya pemahaman tentang pendidikan seks dan sikap/perilaku seks di kalangan remaja SMP dan SMA di DIY sangat bervariasi, tetapi semuanya berada pada kategori rendah sampai tinggi, dengan rerata persentase terendah $26,3 \%$ dan tertinggi 74,9\%. Hasil lainnya menunjukkan sikap/perilaku remaja terhadap berbagai permasalahan seks di sekitarnya banyak persoalan yang muncul dari jawaban yang diberikan responden yang perlu ditindaklanjuti dalam bentuk program pendidikan seks dan penelitian yang lebih mendalam. Berdasarkan hasil ANAVA dan uji-t menunjukkan ada perbedaan tingkat pemahaman tentang pendidikan seks diantara remaja SMP dan SMA di lima Kabupaten yang ada di DIY, tidak ada perbedaan tingkat pemahaman tentang pendidikan seks ditinjau dari jenis kelamin, tetapi ada perbedaan tingkat pemahaman tentang pendidikan seks ditinjau dan tingkat sekolah, yaitu peserta didik SMA memiliki pemahaman lebih 
tinggi dibandingkan peserta didik SMP.

Berdasarkan hasil penelitian ini dapat disarankan adanya penelitian lebih lanjut terhadap responden terutama tentang penelusuran sikap/perilaku seks mereka, karena dari jawaban yang diberikan pada penelitian ini banyak persoalan yang dikhawatirkan dapat berimbas pada halhal yang tidak diinginkan, terutama untuk perkembangan mereka sebagai geberasi penerus bangsa. Hasil penelitian ini juga diharapkan dapat ditangkap oleh pemilik kebijakan untuk memiirkan perlunya memasukkan materi pendidikan seks di sekolah tingkat SMP dan SMA mengingat pengetahuan mereka yang relatif berada pada kategori rerata sedang.

\section{Ucapan Terima Kasih}

Ucapan terima kasih diucapkan kepada UNY, LPPM dan semua pihak yang telah membantu kelancaran pelaksanaan penelitian ini hingga terselesaikannya laporan, karena atas dukungan tersebut penelitian ini dapat terlaksana dengan baik dan lancar.

\section{DAFTAR PUSTAKA}

Anonim. (2001). Tubuh Wanita serta Perubahan-perubahan yang Dialaminya. Jakarta: Penerbit Gunung Jati.

Anonim. (2010). Waspadai menstruasi dini. Diakses dari www.tempo interaktif. com. pada tanggal 6 Mei 2010 jam 20.15.

Antuni, W., Salirawati, D., Sulistyowati, E. (2011). Survei terhadap Peran Serta Orangtua dalam Penanaman Karakter sebagai Pendidikan Karakter secara Informal. Laporan Penelitian. Yogyakarta: LPPM UNY.

Bigner, J.J. (1994). Parent-Child Relation: An Introduction to Parenting. New Jersey: Prentice Hall.

Ebel, R.L. (1972). Essentials of Educational Measurement. New Jersey: Prentice Hall Inc. Englewood Clift.

Kemendiknas. (2010). Pendidikan Karakter di Sekolah Menengah Pertama. Jakarta: Kemendiknas.

Lanson, L. (1987). Dari Wanita untuk Wanita. Surabaya: Usaha Nasional.

Madan, Y. (2004). Sex Education for Children. Bandung: Mizan Publika.

Monks, F. J., Knoers, A. M. P, \& Haditono. (1998). Psikologi Perkembangan: Pengantar dalam Berbagai Bagiannya. Yogyakarta: Gajah Mada University Press.

Pratiwi, N. (2005). Karena Tabu Harus Tahu: Seputar Seksualitas Remaja. Yogyakarta: Pustaka Anggrek.

Wirahadikusumah, M. (1989). Biokimia, Protein, Enzim, dan Asam Nukleat. Bandung: ITB. 